\title{
The development process and the quality of questioning skills instructional video for english teachers at SMA laboratorium UNDIKSHA Singaraja
}

\author{
I Putu Dipta Priyatna ${ }^{1}$, I.G.A. Lokita Purnamika Utami ${ }^{1}$, Made Hery Santosa ${ }^{1}$, Luh Diah Surya \\ Adnyani ${ }^{1}$ \\ ${ }^{1}$ English Language Education, Language and Art Faculty, Universitas Pendidikan Ganesha, Indonesia
}

\begin{abstract}
Article Info
Article history:

Received Jun 12, 2019

Revised Aug 20, 2019

Accepted Sept 26, 2019

Keywords:

instructional video; questioning skills;

English teachers;

ABSTRACT

The aim of this research is to identify how to develop and how is the quality of a prototype instructional video to help English teachers at SMA Laboratorium Undiksha Singaraja develop their questioning skills in teaching English. This study was a Design and Development research following ADDIE steps: Analysis, Design, Develop, Implementation and evaluation. The study showed that there were four steps to develop the prototype, they were: planning, creating prototype, prototype testing and upgrading the preliminary prototype. Also, the study suggested that the prototype was considered a good instructional video for developing questioning skills. Each evaluator completed a quantitative questionnaire and made qualitative comments. The quantitative analysis scored $98 \%$ for content, $93 \%$ for media, and $90 \%$ from users. Those numbers are categorized as very good product where it does not need any revision. Indeed, qualitative analysis gained some suggestions and comments from the experts where there are some weaknesses in the area of content and media. Though there were some revisions for the prototype, the prototype was considered as a good prototype to be finalized later as a ready-to-use product. Implication for future researcher to develop the prototype to a final product for English teachers' professional learning is mentioned.
\end{abstract}

Copyright (C) 2019 Department of English Teaching. All rights reserved.

Corresponding Author:

I Putu Dipta Priyatna,

English Language Education, Language and Art Faculty, Universitas Pendidikan Ganesha, Indonesia

Jalan A.Yani no 67, Singaraja,Bali, 81116.

Email: diptapriyatna@gmail.com 
Introduction

According to the "permendikbud" number 19 in 2005 about the National Education Standards, teachers have to be able to master basic pedagogical, professional, personal, and social competence. All of those competencies have to be mastered by all teachers in the educational field. By meeting those four requirements of the national education standard, the teachers will be recognized by the government as professional teachers, and be able to teach and be certified as a professional teacher. There are eight basic teaching skills that the teacher should have. Those are; opening and closing the class, questioning skill, reinforcement skill, explaining skills, making variations, classroom management, guiding small group discussions, and teaching small groups and individuals. (Suwarna, dkk, 2006). By mastering the basic teaching skills, a teacher is expected to be able to create an active classroom atmosphere and stimulate students to participate in asking, questioning and expressing ideas. (Uno, 2012). As to reach the standards of secondary school in its relevance to "Permendikbud" number 22 year 2016.

One of the basic teaching skills that the researcher found interesting is the questioning skills. (Abdullah, 2007) stated that the use of questioning skills is essential to systematic investigation in any subject area. The questions that are used in teaching and learning process are design to assist students' critical thinking towards the subject that is given in the classroom. Furthermore, he also stated that by giving a good question will enable the students to seek and understand the problems to guide the students toward further investigation for a deeper understanding of the concept being taught by the teacher.Question is a verbal speech to ask for answer or response from the listener (Wati, 2010). Meanwhile, According to Oxford dictionary, skill is the ability to do something well. Not all people have the skill because it is the ability that required a lot of practice and learning. In the relation to education, skills is the ability that both teachers and students should have. It can be trained and developed by every single individuals to improve the teaching and learning process. Form the explanation above it can be stated that questioning skill is an activity that shows the ability to ask question effectively.

Teachers can learn the questioning skills from the conventional way such as reading from the books. However, technology plays an important role in people's day-to-day life and can be used effectively for various aspects in education field. In fact, in this modern era, technology enables varieties of different way of learning which were found more attractive and effective. (Almurashi, 2016) found that the use of Youtube in a form of video can play a vital role in helping pupils understand their English lessons, improve their performance, and advance their understanding of English. Additionally, the instructional video can play as the leading role in helping learners understand their English lessons. The YouTube website is regarded as one online material that can be integrated into traditional English lessons for example the questioning skills. There are two types of questioning skills, namely basic questioning skills and further questioning skills. According to Fathoni (2018), basic questioning skills are questions or question phrases put forward by the teacher when the lesson begins. Whereas further questioning skills are advanced questions given by the teacher after explaining the learning material. Advanced questioning skills aim to encourage students to actively participate in the learning process, triggering students' initiative to ask questions and think critically. The function of advanced questions is to improve students' ability to find, process and assess information in full, develop ideas in discussions and provide opportunities for students to obtain more results than usual.

There are four reasons why teachers need the basic and further questioning skill, such as: 1) teachers is the centre of learning who provides information to the students while the students are the passive receivers, 2) the students always have questions from their families and surroundings and share their opinion, 3) Students' Active Learning (SAL) program demands the participation from the students, and 4) the inappropriate view which states that asking question to the students is used to evaluate the students' learning result only. Basic questioning has something to do with how the teacher presents the question to the students. It has 6 essential components to be mastered (Abdullah, 2007) as follows: 1) expressing the question, 2) focusing, 3) distribution, 4) redirecting, 5) giving thinking time, 6) prompting. The components of good further questioning skill according to Sukirman (2012), as follows: 1) arrange the question based on the cognitive stages by Bloom such as remembering, understanding, applying, analyzing, evaluating and creating, 2) organize the question from the simple to complex questions, 3) use probing question, 4) establish and maintain teacher-students interaction.

According to Dale (1969), Cone of Experience is related to learning theory with audiovisuals. John Dewney's educational theory, a figure in the flow of progressivism and leadership from James Finn, a doctoral-level student on the field of audiovisual communication into learning technology, was united into the conical theory of Dale's experience. Finn's idea of the integration of systems and processes was able to cover and broaden Edgar Dale's ideas about the interrelationship between materials and the learning process. The types of media can basically be classified into three major groups, namely print media, electronic media and real objects or reality. 
SMA Laboratorium Undiksha Singaraja is a reputable senior school in Bali, especially in Buleleng regency. Making sure that the teaching process is working effectively is crucial for the teacher to accomplish. Need analysis was conducted in order to find the needs of this study, which are to analyse how the questions were delivered by the teachers, and to analyse the type and quality of the instructional video to be developed. Based on the need analysis conducted in SMA Laboratorium Undiksha Singaraja, the researcher found that the question given by the teacher were not following all of the aspect of the basic questioning skills which are; expressing the question, focusing, distribution, redirecting, giving thinking time, and prompting (Abdullah, 2007). The teachers' performance were reaching the score of $28 \%$ to $56 \%$ on the principle of questioning skills, basic questioning skills and further questioning skills. It shows that the quality of the questions delivered were in the poor to fair category. Therefore, the need analysis showed the urgency of developing a media to assist teachers' professional learning to upgrade their questioning skills quality. The study was intended to answer two research questions: 1) how is the video prototype on questioning skills is developed and 2) how is the quality of the prototype video being developed. The study was

\section{Method}

This research was designed as a design and development study (D\&D) to develop instructional video prototype of questioning skills for English language subjects using the ADDIE development model (Analysis, Design, Development, Implementation, and Evaluation). In data of collection the research used interview, observation, filming process, and product judgment. The instruments used were teaching script, expert judgment questionnaires (content and media \& desain experts), and user questionnaire. Teaching script was a script for filming the questioning skills, this involved a teacher model being filmed delivering an English lesson to illustrate how questioning skills is performed. Thus, this teaching script is developed concerning on the component of questioning skills. Questioning skills component were deviated from the theory of Depdikbud (1985), Abdullah (2007) and Sukirman (2012).

Table 1. Components of questioning skills

\begin{tabular}{|c|c|c|c|}
\hline No. & Component & & Sub-component \\
\hline \multicolumn{4}{|c|}{ Questioning skill } \\
\hline \multirow[t]{5}{*}{1.} & Principle & 1. & Being warm and enthusiastic \\
\hline & & 2. & Not to repeat either own answer or students' answer \\
\hline & $\begin{array}{l}\text { Depdikbud } \\
(1985)\end{array}$ & 3. & $\begin{array}{l}\text { Not to give question that invite answer from the whole } \\
\text { class }\end{array}$ \\
\hline & & 4 & Not to ask more than one question simultaneously \\
\hline & & 5 & Not to point a student before giving a question \\
\hline \multirow[t]{6}{*}{2.} & Basic Questioning & 1. & Clear and understandable question \\
\hline & Abdullah (2007) & 2. & Focusing \\
\hline & and & 3. & Distribution \\
\hline & & 4. & Redirecting \\
\hline & & 5. & Thinking time \\
\hline & & 6. & Prompting \\
\hline \multirow[t]{4}{*}{3.} & Further & 1. & Cognitive stages question arrangement \\
\hline & Questioning & 2. & Simple to complex question arrangement \\
\hline & Sukirman (2012). & 3. & Probing Question \\
\hline & & 4. & Teacher-students interaction maintenance \\
\hline
\end{tabular}

The instruments used in this study were validated before preliminary product testing. The were 2 content experts involved who hold S3 and S2 qualification on English language education. For the media and design expert, one expert qualified at technology integration in language instruction was involved. To validate the instruments, cross tabulation through 2 kinds of response, relevant or irrelevant by Gregory (2000) was used. The data analysis was done in two ways, qualitative descriptive and quantitative analysis. Suggestion, respond and critics within the questionnaire given to the content expert, media expert, design expert, students and lecturer were the sources for qualitative data. Their review supported the upgrading process for instructional multimedia for microteaching. Besides, the quantitative data analysis employed descriptive percentage as the attempt to collect a rigorous data from each subject in expert judgments' questionnaire using formula by Tegeh and Kirna (2010) in Suciningsih (2013) below:

$$
\text { Percentage }=\frac{\text { Actuall Sivore }}{\text { SMI }} \times 100 \%
$$


Where:

Actual Score $\quad$ : total answer $x$ weights of each items

SMI : total statements $\mathrm{x}$ highest weight

Measuring the percentage of total subjects, the researcher used the formula:

Where:

$$
\mathrm{P}=\frac{\mathrm{F}}{\mathrm{N}}
$$

F : total percentage of all subjects

$\mathrm{N} \quad$ : total subjects

The revision is highly needed if the product only had level of accomplishment less than 75\%. It was done in the development of first product process according to expert judges' review.

\section{Result and Discussion}

This study is research and development study to create instructional video focussing on questioning skills for the English teacher in Senior High School. The purpose of this video are defining the appropriate instructional video and measuring the quality of the prototype. The answer of the first research question were answered through the need analysis. The process of the prototype development and the examination were involved in answering the second research question of this study.

Need analysis was conducted in order to find the needs of this study, which are to analyse how the questions were delivered by the teachers, and to analyse the type and quality of the instructional video to be developed. The need analysis was conducted in four different classes with four English teachers in SMA Laboratorium Singaraja. It was found that the teachers' performance were reaching the score of $28 \%$ to $56 \%$ on the principle of questioning skills, basic questioning skills and further questioning skills. It shows that the quality of the questions delivered were in the poor to fair category. The measurements of respondent answer used the scoring category by Arikunto (1998) as cited in Kamelta (2013).

The teachers that were involved in the observation stages were all English teacher teaching in a different classes. The observation check list were consist of fifteen different aspect within the three main aspect of questioning skills. The main aspect were 1) the principle of questioning skills: being warm and enthusiastic, not to repeat either own answer or students answer, not to give question that invite answer from the whole class, not to point a student before giving a question, 2) basic questioning skills: expressing the question, focusing, distribution, redirecting, thinking time, prompting, and 3) further questioning skills: arrange the questions, simple to complex question, probing and teacher-students interactions.

\section{The Process of Developing the Instructional Video Prototype}

The preliminary prototype was design through planning, creating prototype, prototype testing and upgrading the preliminary prototype. There were several processes involved in the planning process such as deciding setting and time, teaching preparation and content validation. The setting of the video shoot took place in 12 MIPA 1 Class in SMA Laboratorium Undiksha. The preparation of the teaching simulation for the video shoot were involving some steps, such as creating the teaching script. The Script had gone to several development since it got revised several times in order to be validated by the supervisors. The teacher were the researcher itself. It was proved by the supervisor that because of the time efficiency and the effectiveness. The development of the prototype was based on the three phases. Filming, editing and prototype finalization. The whole filming process took for 5 weeks and were involving several processes. The editing process was done by the editor because it requires certain skills and knowledge to be able to edit and make the suitable video. These are the steps of the editing process done by the editor using Adobe Premiere Pro CC 2019, such as video cutting, audio cutting media component insertion (text, icon, images and animation). After the editing process is finished, the prototype then tested by the expert judges. There were two experts involved in this process. The first expert was concerning in the content of the prototype, and the second expert was focusing on the media and design of the prototype.

\section{The Quality of Instructional Video Prototype}

The result and evaluation was done based on the score and feedback that were given by the experts and the users through the questionnaires. There were three different questionnaire that were used to find the result and evaluation. The first was content expert judgments, media and design expert judgments, and the user field try out.

a. Content expert judgment result 
The content expert judgment was presenting 10 components that were intended to measure the three aspects of questioning skills such as the principle of questioning skills, basic questioning skills and further questioning skills. The score of the questionnaire was designed in the range from 1 as the lowest score to 5 as the maximum score. The Score from 1 to 3 was coded as "NR" (not relevant) and the score from 4 to 5 was coded as "R" (relevant).

b. Media and design expert judgment result

The result of the media and design judgment was calculated qualitatively and showed a result of $93 \%$. The prototype is considered very good and does not need a major improvement. However, the expert were suggesting several suggestion to improve to weaknesses of the prototype. The media and design expert found inconsistency of the words chosen in the narration at 00:47 second. He suggested that the words has to be consistent weather to use gerund, noun, or verb. The second feedback was to put a credit to everyone who were involved in the video. The existence of the prototype will not be possible without the help of everyone that were voluntarily help this research.

c. Field try out result

Four English teachers in SMA Laboratorium Undiksha Singaraja were involved in the prototype testing. The users used the prototype with a questionnaire consist of 15 components to assess its relevance to their needs, language use, media components and material presented. Teacher I the percentage of questioning skill is $92 \%$. The response from the teacher was positive and can be categorized as very good. The teacher also leave some comments saying that "it would be good if it shows the whole teaching process. Then it can be obviously seen which questioning type will match with the learning steps that focussing on the demand of $21^{\text {st }}$ learning century activities". Teacher II the percentage of questioning skill is $93 \%$. The teacher II suggested that it would be better if the video uses one theme in a meeting. In the comments she said "overall is very good, I personally think that it would be better if the instructional uses the only one theme in a meeting. You may take the procedure text only or whatever it is relevant to the study". This comment is similar with the teacher I. She gave her thought of making the video in one topic. The reason has been explain before where the goals of this video is to create an instructional video that can covers several topics in every grades of senior high school level. Because of that reason, it was not possible to do what has been suggested by the user. Teacher III the percentage of questioning skill is $90 \%$. Teacher III was satisfied with the video it shows from the total score she gave. She also suggested that the use of attracted image will be better. She also said that the grayscale past was not clear to be seen. The suggestion will be followed up in the development of the prototype. Teacher IV the percentage of questioning skill is $85 \%$. The suggestion given by teacher IV was to create a whole class discussion instead of focussing one-to-one teacher to student discussion. The classroom sitting arrangement has to be varied in order to create the feeling of teacher-students interaction. She also stated that it would be great if the teacher provides the authentic learning media so the student could visualized or capture the concept more easily.

d. Upgrading the prototype

The process of upgrading the prototype was done based on the review from expert judges and the users. Before the video was judged by the experts. The supervisors gave their first look at the prototype. Several suggestion were given by the supervisors not all of the comments and suggestions can be implemented in the upgrading stage due to several reasons that has been explained previously. However, most of the comments and suggestions were followed up and implemented in this stage of upgrading the prototype, such as adding subtitles, developers, credit, logo, narration, and the target of who this product is targeting to.

Teachers need to always improve their quality as teachers play important role within teaching and learning process (Shah \& Masrur, 2011). Teachers learning can be done through formal ways or informal ways. The one informally is mentioned as professional learning. This professional learning is also done by English teachers in Indonesia and is considered more self-driven (Utami \& Prestridge, 2018), it means teachers control when, where and how the learning to be done. One of the example is learning through a media that can be done independently without tutor. The development of this prototype was motivated by the lacking quality on questioning skills performed by English teachers at SMA Laboratorium Undiksha.

The instructional video of questioning skills was developed according to the theory by Abdullah, (2007) and Sukirman, (2012) as the grand theory of this study. It is stated that the questioning skills are divided into two aspect which are basic questioning skills and further questioning skills. The basic questioning skills has six essential component such as: expressing the question, focusing, distribution, redirecting, giving thinking time, and prompting. Meanwhile, further questioning skills has four different components such as: arrange the question, organize the question, probing, teacher-students interaction. All of the components were explained in the product of this research. After deciding the goal and the concept, the researcher validated the teaching script to validate the content of the script to be matched with the grand 
theory. After the script was validated. The researcher did the filming process, editing and assembling the prototype. The content expert, media and design expert and the users tested the first prototype and gave their expertise through the scoring and suggestions regarding any weaknesses that has to be improve in the development stage of the prototype. The content of the prototype were given a total score of $98 \%$. The media and design on the other hand were given a score of $93 \%$. Furthermore the score of all 4 users were calculated and showed a result of $90 \%$. According to Agung (2010), the result indicates that the prototype is very good in which achieve the highest level of accomplishment.

In the previous research conducted by Prabawati, (2014). The research and development study was aimed at developing a linear instructional multimedia of questioning skill and explaining skill for microteaching class in English Education Department, Undiksha. This study employed 5 steps of development which was adapted from Gall, Gall and Brog by sutopo (2009). A similar process was conducted in this research. Using the same theory of questioning skills by Abdullah, (2007) and Sukirman, (2012) stating that the questioning skills is divided into two which are basic questioning and further questioning skills. This research also using the same method of data collection which was started by observation and interview to analyse the needs and the problems occurs. The differences is in the target of the product which this research is targeting the English teacher in senior high school. The goals of this research is to create a product that can be access by the teacher effectively. Other differences with the previous research is that this research has many different topics that can be found in every grades in senior high school. Whereas the previous research was creating a whole teaching activity that only has one topic of the 10th grade. The weaknesses on that is that other teacher cannot relate the theory to the topic they use in the class. The reason why using many different topics is so that every English teacher in the senior high school can relate the theory to the topic used in the class.

It can be said that the development of linear instructional video is significantly needed Yuliawati, Mahmud \& Muliati.(2016) mention how students' critical thinking is largely influence by tachers' questioning skills. In this study, the prototype gave a positive impact and respond from the users that were very satisfied with the score of $90 \%$ of the product. Despite the excellent score by the users, there are still some weaknesses such as the quality of the animation that can be improved in the next development or other related research. The comments from the experts and the users were used as the qualitative analysis of the product. The comment were mostly positive yet there are some minor weaknesses that were fixed in the upgrading process such as adding subtitles, developers, credit, logo, narration, and the target of who this product is targeting to. Overall, the product was successful to facilitate the teacher an instructional video about questioning skills that the teacher in SMA Laboratorium Undiksha found interesting and was very good. The researcher hopes that this product is not only can be used by the English teacher in SMA Laboratorium Singaraja but also every English teacher in Indonesia that are interested in mastering the knowledge of questioning skills. Despite the good quality of the prototype, it has not yet evaluated effectively as the research was a design and development research not a $\mathrm{Rn} \mathrm{D}$ product. Therefore there is a call for future research to evaluate the prototype through a more rigorous testing, for example, through an experimental study to see the impact of the product. Thus, final product can be developed based on the result of the evaluation.

\section{Conclusion}

The finding showed that this study was done to create instructional video focusing on questioning skills for the English teacher in Senior High School. The purpose of this video are defining the appropriate instructional video and measuring the quality of the prototype. The instructional video explained the theories of questioning skills and the examples of every components in both basic and further questioning skills. The video contained several topic in English subject that can be found in every grades in senior high school level. The purpose was to enable every English teacher to master their questioning skills and enable to learn from related topic that they can use in the teaching process. The quality of the product was measured by qualitative analysis and quantitative analysis.. The quantitative analysis for the product showed the score of $98 \%$ for its content, $93 \%$ for its media and design, and a total of $90 \%$ score for the users. This score showed that the product achieved a high level of accomplishment. The study suggests that English teachers are eager to improve their instructional quality but need a media to assist them. Future researchers are encouraged to develop this prototype to a final product that is ready to be distributed for teachers' professional learning. This is important as it may give support for teachers' continuous professional development. 


\section{References}

Abdullah, Rohana. (2007). Bahan Ajar Cetak: Bahasa Inggris (Printed Learning Material: English). Jakarta: Direktorat Jendral Pendidikan Tinggi, Dinas Pendidikan Nasional. Retrieved from www.pjipgsd.dikti.go.id.

Almurashi, W.A. 2016. The Effective Use of Youtube Videos For Teaching English Language in Classrooms as Supplementary Material at Taibah University In Alula. International Journal of English Language and Linguistics Research Vol.4, No.3, pp.32-47

Dale, E. (1969). "The Cone of Experience" from Audio-Visual Methods in Teaching, $1^{\text {st }}$ Edition.

Depdikbud (1985). Panduan Pengajaran Mikro 1 (Microteaching Guidance 1). Jakarta: Departemen Pendidikan dan Kebudayaan.

Fathoni, T. (n.d.). Keterampilan Bertanya-Direktori File UPI. Retrieved March 12, 2018, from file.upi.edu:sd

Gregory, R. (2000). Psycological Testing: History, Principles and Aplications. Boston: Allyn and Bacon.

Kamelta, Edno. (2013). Pemanfaatan internet oleh mahasiswa jurusan teknik sipil fakultas teknik universitas negeri padang. State University of Padang.

Peraturan Pemerintah Nomor 19 Tahun 2005 Tentang Standar Nasional Pendidikan

Permendikbud Nomor 22 Tahun 2016 tentang Standar Proses Pendidikan Dasar dan Menengah

Prabawati, P.P.R.W. (2014). The Development of Linear Instructional Multimedia in Questioning Skill and Explaining Skill for Microteaching Class in English Education Department Undiksha. Unpublished thesis: Undiksha

Shah, Syed Manzoor Hussain.; Masrur, Rehana. (2011). Impact of microteaching skills on the performance of primary school teachers. Gomal University Journal of Research. 27(1), 15-29.

Suciningsih, K. (2013). Pengembangan video pembelajaran pada mata pelajaran bahasa Indonesia kelas III semester II tahun pelajaran 2012/2013 di SD negeri 1 bondalem kecamatan tejakula kabupaten buleleng. Unpublished Thesis. Singaraja: Ganesha University of Education.

Sukirman, Dadang. (2012). Microteaching [DX Reader version]. Jakarta: Direktorat Jendral Pendidikan Islam Kementrian Agama RI.

Suwarna, dkk. (2006). Pengajaran Mikro. Pendekatan Praktis dalam Menyiapkan Pendidik Profesional. Yogyakarta: Tiara Wacana.

Taufik, R. (2013). Kemampuan Guru Menerapkan Keterampilan Bertanya pada Pelajaran Sosiologi di Kelas XI SMA Islamiyah Pontianak.

Utami, I.G.A. Lokita Purnamika \& Prestridge, S. 2018. How English Teachers Learn In Indonesia: Tension Between Policy-Driven And Selfdriven Professional Development. Teflin Journal,29(2): 245-265

Uno B. Hamzah, Nurdin Mohamad. (2012). Belajar dengan Pendekatan PAILKEM.Jakarta: Bumi Aksara

Wati, Widya. (2010). Makalah strategi pembelajaran keterampilan dasar guru (online ). Program Pasca Sarjana Universitas Negeri Padang. Retrieved from http://widya57physicsedu.files.wordpress.com/2010/12/no-29-widya-wati-06-keterampilan-dasarguru.pdf

Yuliawati, Y., Mahmud, M., Muliati. (2016). Teacher's Questioning and Students' Critical Thinking in EFL Classroom Interaction. ELT Worldwide Journal of English Language Teaching. 3(2) http://ojs.unm.ac.id/ELT/article/view/2261 